\title{
Faktor-faktor yang Mempengaruhi Kinerja Pegawai PDAM kota Balikpapan
}

\author{
Tamzil Yusuf' ${ }^{1}$, Rihfenti Ernayani \\ ${ }^{1,2}$ Universitas Balikpapan, Balikpapan, Indonesia \\ rihfenti@uniba-bpn.ac.id
}

\begin{abstract}
This research is conducted to know and analyze the factors that influence the performance of employees, either partially or simultaneously on the influence of Job Characteristics, Organizational Climate, and Job Satisfaction on Performance of Balikpapan City PDAM employees. This research is a quantitative research, using test equipment that is classical assumption test ; test of normality, multi colinearity, autocorrelation, heteroskedastisitas, and hypothesis test that is $F$ test and t test. Sampling was done using purposive sampling technique, with amount of data counted 40 and processed by using program of SPSS. The result of research shows that partially there is influence of job characteristic to employee performance, there is influence of organizational climate of employee performance, and there is influence of job satisfaction to performance of Balikpapan City PDAM employee. Simultaneously the characteristics of the organization's work climate and job satisfaction affects the performance of Balikpapan City PDAM employees.
\end{abstract}

Keywords: Job Characteristics, Organizational Climate, Job Satisfaction, Employee Performance

\begin{abstract}
Abstrak
Penelitian ini dilakukan untuk mengetahui dan menganalisis faktor-faktor yang mempengaruhi kinerja pegawai, baik secara parsial maupun secara simultan mengenaipengaruh Karakteristik Pekerjaan, Iklim Organisasi, dan Kepuasan Kerja terhadap Kinerja Pegawai PDAM Kota Balikpapan. Penelitian ini merupakan penelitian kuantitatif, dengan menggunakan alat uji yaitu uji asumsi klasik; uji normalitas, multikolinearitas, autokorelasi, heteroskedastisitas, dan uji hipotesis yaitu uji $\mathrm{F}$ dan uji t. Pengambilan sampel dilakukan menggunakan teknik purposive sampling, dengan jumlah data sebanyak 40 dan diolah dengan menggunakan program SPSS.Hasil penelitian membuktikan bahwa secara parsial terdapat pengaruh karakteristik pekerjaan terhadap kinerja pegawai, terdapat pengaruh iklim organisasi terhadap kinerja pegawai, dan terdapat pengaruh kepuasan kerja terhadap kinerja pegawai PDAM Kota Balikpapan. Secara simultan karakteristik pekerjaaniklim organisasi dan kepuasan kerja berpengaruh terhadap kinerja pegawai PDAM Kota Balikpapan.
\end{abstract}

Kata Kunci: Karakteristik Pekerjaan, Iklim Organisasi, Kepuasan Kerja, Kinerja Pegawai

\section{Pendahuluan}

Dalam rangka meningkatkan kinerja pegawai PDAM Kota Balikpapan, organisasi atau institusi harus menyelaraskan antara tujuan organisasi dengan tujuan pribadi setiap pegawai. Organisasi harus memahami kebutuhan setiap pegawainya sehingga pegawai merasa nyaman dan puas dalam bekerja. Terpenuhinya segala kebutuhan pegawai akan memberikan rasa puas dalam bekerja sehingga akan timbul suatu kesadaran dan tanggung jawab pegawai untuk menyelesaikan setiap tugas atau pekerjaannya. Faktor-faktor yang dapat mempengaruhi kinerja pegawai antara lain karakteristik pekerjaan, iklim organisasi dan kepuasan kerja

Karakteristik pekerjaan adalah uraian pekerjaan yang menjadi pedoman 
dalam bekerja dan dalam pelaksanaannya bisa mencapai kepuasan. Menurut Hackman dan Oldham (Luthan, 2005), ada lima dimensi karakteristik pekerjaan yaitu: Task identity, Task Significance, Skill Variety, Autonomy dan Feed back. Sementara Gibson et al. (1994) menyatakan bahwa iklim organisasi diartikan sebagai seperangkat sifat-sifat lingkungan kerja yang dirasakan baik secara langsung maupun tidak langsung oleh pegawai dan diduga berpengaruh terhadap perilaku kerjanya. Litwin dan Stringers (1968) memberikan dimensi iklim organisasi sebagai berikut: rasa tanggung jawab, standar atau harapan tentang kualitas pekerjaan, ganjaran atau reward, rasa persaudaraan, dan semangat tim.Handoko (2005) mengemukakan kepuasan kerja adalah keadaan emosional yang menyenangkan atau tidak menyenangkan bagi para karyawan memandang pekerjaan mereka.Kepuasan kerja disamping dipengaruhi oleh factor kecerdasan emosional juga dapat dipengaruhi oleh karakteristik pekerjaan. Kejenuhan atau kebosanan dalam bekerja akan timbul dalam diri pegawai manakala bekerja hanya sebatas rutinitas, tanpa adanya variasi dan kehangatan dalam pergaulan baik antara pimpinan dengan bawahan maupun dinatara sesam pegawai. Sejalan dengan teori-teori yang ada berkembang dengan kinerja pegawai, maka menarik untuk dilakukan penelitian terhadap kinerja pegawai PDAM Kota Balikpapan yang ditinjau dari persepektif karakteristik pekerjaan, iklim organisasi, dan kepuasan kerja.

Putr (2017) dalam penelitiannya menunjukkan bahwa ada pengaruh positif dari karakteristik pekerjaan dan kepuasan kerja terhadap kinerja karyawan. Penelitian Carmeli (2004), menunjukkan bahwa kepuasan kerja mempunyai pengaruh dalam hubungan antara capaian pekerjaan dan komitmen pekerjaan. Hendy (2012) menyimpulkan bahwa secara simultan karakteristik pekerjaan, kepuasan kerja dan komitmen karyawan terhadap kinerja karyawan mempunyai pengaruh yang signifikan. Sedangkan secara parsial yang memiliki pengaruh signifikan hanya karakteristik pekerjaan, untuk kepuasan kerja dan komitmen pengaruhnya terhadap kinerja tidak signifikan.Lubis (2012) menyimpulkan bahwa terdapat pengaruh signifikan iklim organisasi terhadap kepuasan dan terdapat pengaruh signifikan kepuasan terhadap kinerja karyawan.Mangkunegara (2005), hasilnya membuktikan adanya pengaruh factor dalam motivasi kerja terhadap kepuasan kerja. Sarwoko (2005) hasil penelitian menunjukkan bahwa karakteristik pekerjaan berpengaruh signifikan terhadap kinerja melalui jalur motivasi dan kepuasan kerja.Mulyanto 
menyatakan bahwa karakteristik pekerjaan berpengaruh positif tidak signifikan terhadap kinerja karyawan dan kepuasan karyawan berpengaruh positif tidak signifkan terhadap kinerja karyawan. Narotamma (2015) hasil penelitian membuktikan bahwa terdapat pengaruh positif dan signifikan secara langsung karakteristik pekerjaan terhadap kinerja karyawan melalui kepuasan kerja. dan terdapat pengaruh kepuasan kerja terhadap kinerja karyawan.

Berdasarkan teori dan hasil penelitian tersebut, maka dapat dirumuskan rumusan masalah sebagai berikut : (1) Apakah secara bersama-sama ada pengaruh karakteristik pekerjaan, ilklim organisasi, dan kepuasan kerjaterhadap kinerja pegawai PDAM di Kota Balikpapan?, (2) Apakah secara parsial karakteristik pekerjaan, ilklim organisasi, dan kepuasan kerja berpengaruh terhadap kinerja pegawai pegawai PDAM di Kota Balikpapan?.

Sesuai dengan perumusan masalah di atas, tujuan yang ingin dicapai dalam penelitian ini adalah: (1) membuktikan adanya pengaruh secara bersama-sama karakteristik pekerjaan, ilklim organisasi, dan kepuasan kerja terhadap kinerja pegawai PDAM di Kota Balikpapan. (2) membuktikan adanya pengaruh secara parsial karakteristik pekerjaan, iklim organisasi, dan kepuasan kerja terhadap kinerja pegawai PDAM di Kota Balikpapan.

Hipotesis penelitian dirumuskan sebagai berikut: (1) karakteristik pekerjaan, ilklim organisasi, dan kepuasan kerja secara simultan berpengaruh terhadap kinerja pegawai PDAM di Kota Balikpapan, (2) karakteristik pekerjaan, ilklim organisasi, dan kepuasan kerja secara parsial berpengaruh terhadap kinerja pegawai PDAM di Kota Balikpapan.

\section{Metodologi Penelitian}

Dalam penelitian ini menggunakan pendekatan kuantitatif, yaitu penelitian yang digunakan untuk meneliti sampel tertentu dan pengumpulan data menggunakan instrumen penelitian, dengan desain riset deskriptif. Desain deskriptif bertujuan untuk mendeskripsikan atau menjelaskan suatu variabel secara sistematis, seperti mengetahui seberapa besar hubungan suatu variabel. Pada penelitian ini menggunakan teknik survey dengan cara menyebarkan kuesioner, selanjutnya data yang diperoleh akan diproses dengan cara menggunakan metode statistik berupa program SPSS 20.0 .

\subsection{Identifikasi Variabel}

Penelitian ini dilakukan dengan menggunakan dua variabel yaitu variabel bebas dan variabel tidak bebas. Variabel bebas (independent variabel) yaitu 
Karakteristik Pekerjaan $\left(\mathrm{X}_{1}\right), \quad$ Iklim Organisasi $\left(\mathrm{X}_{2}\right)$, dan Kepuasan Kerja $\left(\mathrm{X}_{3}\right)$.Sedangkan variabel tidak bebas (dependent variabel) yaitu Kinerja Pegawai (Y).

\subsection{Prosedur Penentuan Sampel}

Pemilihan sampel menggunakan purposive sampling yaitu pengambilan sampel berdasarkan kriteria. Adapun kriteria sampel adalah sebagai berikut.

1. Pegawai PDAM Kota Balikpapan dengan masa kerja antara 5 - 10 tahun dengan status pegawai tetap.

2. Bagian pelayanan Publik atau pegawai Non Teknik.

3. Memiliki latar belakang pendidikan sekurang-kurangnya SMA/ Sederajat.

\subsection{Prosedur Pengumpulan Data}

Prosedur atau teknik pengumpulan data primer dan data sekunder dilakukan dengan studi kepustakaan dan menyebarkan kuesioner penelitian. Kuesioner yang disebarkan tersebut terdiri dari 49 pernyataan serta pertanyaan karakteristik responden. Jawaban atas pernyataan-pernyataan yang diajukan kepada para responden penelitian disusun dengan menggunakan format Skala Likert.

Penyusunan skor pilihan jawaban pada setiap pernyataan menggunakan Skala Likert(Supranto, 2006: 86), dengan ketentuan skor 1 (sangat tidak setuju), skor 2 (tidak setuju), skor 3 (kurang setuju), skor 4 (setuju) dan skor 5 (sangat setuju).

\subsection{Teknik Analisis}

Teknik analisis yang digunakan meliputi: (1) uji validitas dan reliabilitas. (2) uji asumsi klasik untuk menguji kelayakan penggunaan model regresi. Uji asumsi klasik itu sendiri terdiri dari uji normalitas, uji multikolinieritas, uji heteroskedastitas, dan uji autokorelasi. (3) metode regresi berganda meliputi uji $t$ (parsial) dan uji F (simultan).

\subsubsection{Uji validitas dan Reliabilitas}

Validitas adalah pernyataan sampai sejauh mana data yang diperoleh dari suatu instrument penelitian dalam hal ini kuesioner dapat mengukur apayang ingin diukur. Karena data penelitian menggunakan skala likert maka digunakan dengan menggunakan program SPSS 20 pada tabel Item-Total Statistic kolom Corrected Item-Total Correlation. Kriterianya jika $r$ hitung lebih besar dari $r$ tabel berarti valid, sebaliknya jika $\mathrm{r}$ hitung lebih kecil dari $r$ tabel berarti tidak valid.

Setelah dilakukan pengujian validitas kuesioner, maka kuesioner tersebut diuji reliabilitasnya. Reliabilitas adalah ukuran yang menunjukkan kestabilan dalam mengukur. Pengukuran reliabilitas dilakukan dengan dua cara yaitu :

(1) Repeated Measure atau pengukuran berulang. Disini pengukuran dilakukan berulang pada waktu yang berbeda, dengan kuesioner atau pertanyaan yang sama. 
Hasil pengukuran dilihat apakah konsisten dengan pengukuran sebelumnya.

(2) One shot, pada tehnik ini pengukuran dilakukan hanya pada satu waktu kemudian dilakukan perbandingan dengan pertanyaan yang lain atau dengan pengukuran korelasi antar jawaban. Pada program SPSS, metode ini dilakukan dengan metode Cronbach Alpha, dimana suatu kuesioner dikatakan reliabel jika nilai Cronbach Alpha lebih bersar dari 0,60 .

\subsubsection{Uji Hipotesis}

Uji hipotesis menggunakan uji f dan uji t, uji $\mathrm{R}^{2}$ serta uji asumsi klasik. Uji $\mathrm{f}$ dilakukan untuk melihat pengaruh secara simultan variabel bebas (X) terhadap variabel terikat (Y), sedangkan Uji t adalah uji parsial untuk melihat secara parsial pengaruh variabel bebas $(\mathrm{X})$ terhadap variabel terikatnya (Y). Uji $\mathrm{R}^{2}$ atau koefisien determinasi adalah nilai statistik yang digunakan untuk mengetahui seberapa besar pengaruh antara variabel bebas terhadap variabel terikat.

\section{Hasil Penelitian}

\subsection{Hasil Uji Instrumen Penelitian}

\section{Hasil Pengujian Validitas}

Pengujian validitas instrumen penelitianuntuk mengetahui koefisien korelasi validitas pada setiap item kuesioner penelitian dilakukan penghitungan dengan menggunakan program SPSS 20 pada tabel Item-Total Statistic kolom Corrected Item-Total Correlation. Kriterianya jika $\mathrm{r}$ hitung lebih besar dari $\mathrm{r}$ tabel berarti valid, sebaliknya jika $r$ hitung lebih kecil dari $r$ tabel berarti tidak valid. Berdasarkan taraf kepercayaan (df) yang dipilih sebesar 95 persen dan alpha 5 persen dengan jumlah sampel penelitian sebanyak 40 responden didapat $r$ tabel sebesar 0,312, sehingga hasilnya valid. Hasil valid tersebut bermakna bahwa indikator-indikator penelitian dapat dipergunakan sebagai alat pengumpul data untuk mengukur variabel Kinerja Pegawai.

\section{Hasil Uji Reliabilitas}

Uji reliabel menunjukkan alat ukur yang digunakan dapat diandalkan. Pengujian menggunakan Cronbach Alphadengan kriteria jika $\mathrm{r}$ hitung $<0,60$ berarti tidak reliabel dan jika $r$ hitung > 0,60 berarti reliabel. Hasil pengujian $\mathrm{r}$ diatas 0,60 yang artinya bahwa indikatorindikator penelitian yang dipergunakan sebagai alat ukur dapat diandalkan untuk mengukur masing-masing variabel.

\subsection{Hasil Uji Asumsi Klasik}

Dalam melakukan analisis data kuantitatif seringkali menggunakan uji persyaratan analisis untuk regresi yang juga sering disebut dengan istilah Uji Asumsi Klasik. Menurut Gujarati (2006) agar model regresi tidak bias atau agar model regresi BLUE (Best Linear 
Unbiased Estimator) maka perlu dilakukan uji asumsi klasik terlebih dahulu yaitu uji normalitas, ujimultikolinieritas, uji heteroskedastitas, dan uji autokorelasi. Berdasarkan hasil uji asumsi klasik dinyatakan bahwa regresi berganda dapat digunakan dalam penelitian ini. Dimana

\subsection{Hasil Analisis Uji Regresi Berganda}

keseluruhan berdistribusi normal, tidak terdapat multikolinieritas, tidak terdapat heteroskedastitas, dan tidak terdapat autokorelasi, sehingga regresi berganda layak dan dapat digunakan dalam penelitian ini.

Tabel 1.Hasil Regresi Berganda

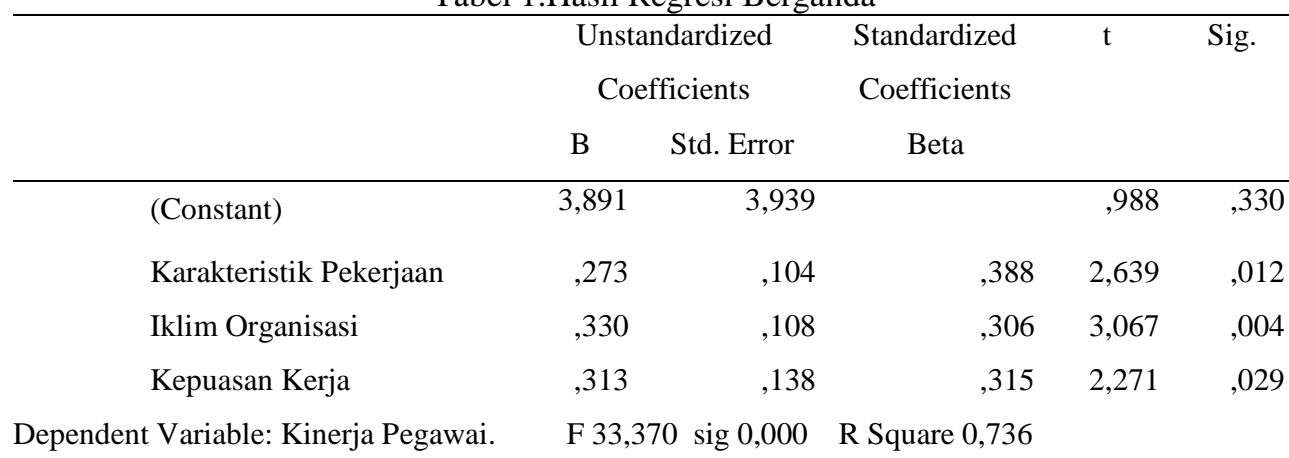

Sumber : data diolah

\subsection{Pembahasan}

\section{Pengaruh Karakteristik Pekerjaan terhadap Kinerja Pegawai}

Hasil penelitian ini membuktikan hipotesis yang menyatakan bahwa karakteristik pekerjaan berpengaruh terhadap kinerja Pegawai. Hal ini ditunjukkan dari hasil uji t, yakni $t_{\text {hitung }}>$ $\mathrm{t}_{\text {tabelatau }}$ 2,639>2,021 serta ditunjukkan dari nilai probabilitas $(\mathrm{sig})<0,05$ atau $0,012<0,05$. Hal ini berarti hubungan karakteristik pekerjaan berperan penting dalam mempengaruhi kinerja pegawai. Hal ini sejalan dengan pendapat Putr (2017), Hendy (2012), Narotamma (2015) dan Sarwoko (2005) yang menegaskan pada dasarnya karakteristik pekerjaan berpengaruh positif terhadap kepuasan dan kinerja karyawan. Namun hasil penelitian ini tidak mendukung penelitian dari Mulyanto (2014) yang menyatakan bahwa karakteristik pekerjaan berpengaruh positif tidak signifikan terhadap kinerja karyawan.Karakteristik Pekerjaan Pegawai PDAM Kota Balikpapan telah baik, hal ini menunjukkan bahwa penetapan kegiatan individu atau kelompok pegawai dalam melaksanakan tugas pekerjaan bisa dilaksanakan dengan baik karena pegawai bisa melaksanakan variasi tugas, identitas tugas, signifikansi tugas dan umpan balik dapat terlaksana dengan baik.Hal ini didukung oleh Robbins (2001) yang mengemukakan karakteristik pekerjaan adalah upaya mengidentifikasikan karakteristik tugas dari pekerjaan, 
bagaimana karakteristik itu digabung untuk membentuk pekerjaan yang berbeda dan hubungannya dengan motivasi, kepuasan kerja dan kinerja karyawan.

\section{Pengaruh Iklim Organisasi terhadap}

\section{Kinerja Pegawai}

Hasil penelitian ini membuktikan hipotesis yang menyatakan bahwa Iklim Organisasi berpengaruh terhadap Kinerja Pegawai. Hal ini ditunjukkan dari hasil uji $\mathrm{t}$, yakni $\mathrm{t}_{\text {hitung }}>\mathrm{t}_{\text {tabel }}$ atau 3,067 $>2,021$ serta ditunjukkan dari nilai probabilitas $($ sig) < 0,05 atau $0,004<0,05$. Hasil penelitian ini mendukung penelitian Lubis (2012) yang menyimpulkan bahwa terdapat pengaruh signifikan iklim organisasi terhadap kepuasan dan terdapat pengaruh signifikan kepuasan terhadap kinerja karyawan.Churiyah (2011) Iklim organisasi sebagai suatu sistem sosial dipengaruhi oleh lingkungan internal dan eksternal. Lingkungan internal meliputi desain pekerjaan, aplikasi teknologi, kultur organisasi, praktek-praktek manajerial, dan karakteristik organisasi, sedangkan lingkungan eksternal meliputi lingkungan sosial, ekonomi, dimana organisasi berada. Panduan lingkungan internal dan eksternal mempengaruhi aktivitas norma, sikap, dan pelaksanaan peran yang pada akhirnya mempengaruhi produktivitas, kepuasan, pertumbuhan organisasi.

\section{Pengaruh Kepuasan Kerja terhadap Kinerja Pegawai}

Hasil penelitian ini membuktikan hipotesis yang menyatakan Kepuasan Kerja berpengaruh terhadap Kinerja Pegawai. Hal ini ditunjukkan dari hasil uji $\mathrm{t}$, yakni $\mathrm{t}_{\text {hitung }}>\mathrm{t}_{\text {tabel }}$ atau 2,271>2,021 serta ditunjukkan dari nilai probabilitas (sig) < 0,05 atau $0,029<0,05$. Hasil ini mendukung penelitian Narotamma (2015) yang membuktikan terdapat pengaruh kepuasan kerja terhadap kinerja karyawan. Namun hasil penelitian ini tidak mendukung penelitian yang dilakukan oleh Mulyanto (2004) yang menyimpulkan bahwa kepuasan kerja tidak berpengaruh terhadap kinerja pegawai.

Hasil temuan ini membuktikan bahwa kepuasan kerja pegawai di kantor PDAM di Kota Balikpapanmerupakan perasaan atau sikap pegawai terhadap pekerjaan yang dilakukannya di kantor PDAM di Kota Balikpapan, yang dapat dipengaruhioleh berbagai macam faktor, baik itu faktor internal maupun faktor eksternal. Tiffin (As'ad, 1995) mengemukakan bahwa kepuasan kerja berhubungan erat dengan sikap dari karyawan terhadap pekerjaannya sendiri, situasi kerja, kerja sama antara pimpinan dengan sesama karyawan.Karena itu, ketika pegawaiyang bekerja di kantor PDAM di kota Balikpapan merasa puas maka hasil kerja yang pegawai selesaikan akan mempengaruhi terhadaptingkat produktivitas pegawai. 


\section{Pengaruh Karakteristik Pekerjaan,}

Iklim Organisasi, Kepuasaan Kerja

\section{Terhadap Kinerja Pegawai}

Hasil penelitian ini membuktikan hipotesis yang menyatakan bahwa Karakteristik Pekerjaan, Iklim Organisasi dan Kepuasan Kerja berpengaruh secara bersama-sama terhadap Kinerja Pegawai. Hal ini ditunjukkan dari hasil uji F, yakni $F_{\text {hitung }}>F_{\text {tabelatau }} 33,370>2,80$ serta ditunjukkan dari nilai probabilitas (sig) < 0,05 atau $0,000<0,05$. Hal ini juga membuktikan bahwa Karakteristik Pekerjaan, Iklim Organisasi dan Kepuasan Kerja secara bersama-sama mempunyai kontribusi mempengaruhi Kinerja Pegawai sebesar $73,6 \%$. Sisanya sebesar $26,4 \%$ merupakan kontribusi variabel - variabel lain terhadap variabel Kinerja Pegawai namun tidak diteliti (epsilon).

Kinerja pegawai PDAM di Kota Balikpapan pada dasarnya merupakan suatu proses dan hasil kerja yang bersumber dari kemampuan para pegawai dalam melaksanakan tugas dan fungsinya sebagai pegawai. Artinya kinerja pegawai pada PDAM di Kota Balikpapan dapat diketahui dari kuantitas dan kualitas pencapaian tugas-tugas sehingga tinggi atau rendahnya kinerja ini dapat dilihat dari kuantitas dan kualitas pencapaian tugasnya.

\section{Kesimpulan}

Beberapa hal yang dapat disimpulkan adalah sebagai berikut : (1) Karakteristik Pekerjaan secara parsial berpengaruh terhadap Kinerja Pegawai, (2) Iklim Organisasi berpengaruh terhadap Kinerja Pegawai dan (3) Kepuasan Kerja berpengaruh terhadap Kinerja Pegawai. (4) Secara bersama-sama terdapat pengaruh Karakteristik Pekerjaan, Iklim Organisasi dan Kepuasan Kerja terhadap Kinerja Pegawai. (5) Karakteristik Pekerjaan, Iklim Organisasi dan Kepuasan Kerja secara bersama-sama mempunyai kontribusi mempengaruhi Kinerja Pegawai sebesar $73,6 \%$. Sisanya sebesar $26,4 \%$ merupakan kontribusi variabel - variabel lain diluar dari variabel yang diteliti.

\section{Daftar Pustaka}

As'ad, M. (1995). Psikologi Industri. Jakarta: Liberty.

Carmeli, A., \& Freund, A. (2004). Work Commitment, Job Satisfaction, And Job Performance: An Empirical Investigation. International Journal of Organization Theory and Behavior. Boca Raton: Fall, Vol 7 Edisi 3.

Churiyah, M. (2019). Ambiquitas Peran. http: madzatul.blogspot.com.

Gibson. (1994). Organisasi. Jakarta: Erlangga.

Handoko, H. (2004). Manajemen Sumber daya Manusia. Yogyakarta: BPFE.

Hendy, H. (2012). Pengaruh Karakteristik Pekerjaan, Kepuasan Kerja dan 
Komitmen Terhadap Kinerja Karyawan. Jurnal Ekonomi dan Bisnis, , Volume 5, Nomor 2, .

Litwin, G. H., \& Stringer, R. (1968). Motivation and Organisational Climate. Boston: Harvad University Press.

Lubis. (2012). Pengaruh Karakteristik Individu, Karakteristik Pekerjaan,. Trikonomika, ISSN 1411-514X.

Luthans, R. (2002). Organisation Behavior. New York: McGrawHill.

Mangkunegara, A. P. (2005). Evaluasi Kinerja SDM. Bandung: Refika Aditama.

Mulyanto. (2014). Analisa Pengaruh Karakteristik Pekerjaan Terhadap Kepuasan Kerja Di Hotel D'SEASON Surabaya. Jurnal Hospitality dan Manajemen Jasa, Vol 2 No 2.

Narotamma, H. (2015). Pengaruh Karakteristik Pekerjaan dan Kompenssasi Finansial Terhadap Kinerja Karyawan. E-Jurnal Manajemen Unud, Vol 4 No 12.

Putr, G. S. (2017). Pengaruh Karakteristik Pekerjaan dan Kepuasan Kerja Terhadap Kinerja Karyawan . https://ejournal.undiksha.ac.id, Vol 8 No 2.

Robbins, S. (2001). Organization Bahaviour. New Jersey: A Simon \& Schuster Company, Englewood Cliffs.

Sarwoko, E. (2005). Analisis Jalur Pengaruh Karakteristik Pekerjaan, Motivasi, Kepuasan Kerja Terhadap KinerjaKaryawan (Studi di PT. Perusahaan Listrik Negara (Persero) Distribusi Jatim Area Pelayanan dan Jaringan Malang). Jurnal Ekonomi Modernisasi, No 1 Vol 1.
Supranto, J. (2006). Pengukuran Tingkat Kepuasan Pelanggan Untuk Menaikkan Pangsa Pasar. Jakarta: Rineka cipta. 